\title{
The Anomali on Technology Readiness Profile of Elementary School Teachers in Online Learning Amid Covid-19
}

\author{
*Dwi Sulisworo, Ahmad Dahlan University, Indonesia, dwi.sulisworo@uad.ac.id \\ Dian Hidayati, Ahmad Dahlan University, Indonesia \\ Rahmad Bala, Islamic Studies College of Kupang, Indonesia \\ Rahmad Nasir, Muhammadiyah Teacher Training and Education College of Alor, Indonesia \\ Fitriah, Muhammadiyah Teacher Training and Education Institute of Maumere, Indonesia \\ *Corresponding Author
}

\begin{abstract}
The Ministry of Education and Culture (MOEC) of Indonesia issued a policy for online learning in all schools, including provinces with limited internet facilities. This study aims to explain the readiness of elementary school teachers in the rural or remote areas in applying online learning. The method used in this study is was ex-post facto. Technology readiness is was measured based on four factors: Optimism (4 items), Innovativeness (4 items), Discomfort (4 items), and Insecurity (4 items). The Likert scale ranged from 1 (Strongly Disagree) to 5 (Strongly Agree). The analysis used Two-way ANOVA and Cluster Analysis. Data from field observations were used to provide a deeper explanation of the statistical analysis. The analysis shows that three segments appear namely Explorers, Pioneers, and Laggards. The immediate implementation of the online learning has caused the Skeptics and Paranoid segments not appear. This study implies that educational policy-makers need to pay attention to the Internet access and the availability of mobile phones as constraints in online learning in rural or remote areas.
\end{abstract}

Keywords: COVID-19, Elementary School, Online Learning, Rural Area, Educational Technology, Social Presence, Technology Readiness

$\begin{array}{lll}\text { Received: } 19.12 .2020 & \text { Accepted: 22.01.2021 } & \text { Published: 03.02.2021 }\end{array}$

\section{INTRODUCTION}

In the Industrial Revolution 4.0 era, many schools began implementing online learning (Mulyani et al. 2019; Santoso 2018), so these schools had started to prepare various policies for their implementation (Soetan \& Cokerb 2018; Faridi \& Ebad 2018). It's just that schools in remote areas that start implementing online learning are still rare. Due to this COVID-19 outbreak, MOEC requires all schools to implement online learning so In order that all schools run sudden online learning. Several factors need to be anticipated for the success of online learning in this situation, such as infrastructure readiness, teacher, and student readiness. In remote areas, the aspect that needs to be studied is the issue of technology. This issue is essential in online learning (Geng et al. 2019; Kamahina et al. 2019; Sumuer 2018). Nearly all educators today agree that the internet is a useful tool for learning media (Wong et al. 2019).

WHO has warned COVID-19 as a pandemic because it has spread to almost all countries in the world, including Indonesia. The COVID-19 pandemic has a huge impact on various sectors of life, such as the economic, social, and education sectors. In Indonesia, the COVID -19 pandemic strongly affects the education sector, both formal and non-formal institutions. Mitigation of COVID-19 encourages MOEC to issue a policy to house students and carry out learning from home. This policy is stated in Official Letter Number 3 of 2020 concerning Prevention of Covid-19 in the Education, and Number 4 of 2020 on the Implementation of Education in Emergency. Educators have the challenge of conducting online learning. Temporary suspension of teaching and learning activities in schools does not necessarily make the student learning process stalled. Students can keep studying online. Teachers have been conducting this learning to provide a meaningful learning experience for students, without being burdened with the demands of achieving all curriculum goals and objectives for grade promotion or graduation. Learning activities and assignments can vary among students, according to their interests and conditions, including the gap in access or learning facilities at home.

This policy certainly applies in Nusa Tenggara Timur (NTT) as one of the rural areas in Indonesia. Problems in education arise when the level of quality among regions in supporting the implementation of online learning is not the same. The MOEC policy was responded to by the Governor through Decree Number: $122 / \mathrm{KEP} / \mathrm{HK} / 2020$ concerning the Status of Emergency Response to Disease Outbreaks of Covid-19 Diseases in NTT. To follow up on the decision, the governor instructed the Mayors of NTT, the 
head of the education unit, through Instructions number 443/102/Pk/2020 Regarding Increased Awareness of the Risk of Transmission of Covid-19 Infection in the Education Unit. The contents of the Instruction are the period of home learning, which first was until April 22, 2020, extended to May 30, 2020, and the session that the students went to school again on June 1, 2020. The instruction also provides a policy of learning methods with various methods, online, offline, and assignments.

The implementation of online learning in NTT succeeded or at least went well, especially in the regions of the Provincial Capital (Kupang City) and Regency Cities. Students who live far from the provincial capital have difficulty accessing internet signals. This difficulty increases in deeper remote areas.. Some sub-districts in NTT do not even have an internet network. One of the indications is that electricity has not yet reached the District eventhough Internet facilities have reached various regions in NTT from Telkomsel, Indosat, and XL providers. In more remote areas, electricity infrastructure and internet networks are still limited. This condition affects much in teaching and learning activities in conducting online learning as instructed by the government. This situation has been investigated previously, especially on the student response to online learning in Maumere, one of the districts in NTT (Sulisworo et al., 2020).

The schools most affected during the COVID-19 mitigation period are elementary schools. The schools located in the Provincial Capital and the Capital District of online learning are still running normally. However, there are still many schools located in remote villages or islands that do not have the internet access. In one hand, this limitation is the obstacle to apply online learning. These schools are, in fact, the most dominant school in terms of the total number of students. In the other hand, so far, there is a policy that, on average, children of elementary school age are not allowed to have a mobile phone. Indeed, a policy that turns into online learning will face its obstacles.

However, there is optimism in online learning in Indonesia. In the period before the Covid-19 outbreak, MOEC has plans to develop Indonesian education by utilizing information and communication technology. A long time before the present ministerial era, similar policies have also been applied as outlined in the Strategic Plan of the MOEC 2015-2019. It states the need for the use of ICT in the education sector. To support online learning, MOEC has been preparing much learning facilitations. MOEC has been developing distance learning applications based on the portal and android "Rumah Belajar". Students and teachers can access their portal.

The Covid-19 mitigation period is a transition forcing from a traditional 'face-to-face' learning environment into a new 'online learning' environment or 'massive open online courses' (MOOCs). Online learning is not just an activity carried out through the internet (Cole et al., 2014) but it is more than that. Although there is no standardized definition of online learning, teachers and students expect to meet their outcomes as same as classroom learning (Cole et al., 2014) as productive learning communities (Garrison, 2009) and to achieve particular competencies (Gray \& DiLoreto, 2016; Alshare et al., 2011). With such expectations, there will be various obstacles encountered in their implementation. This challenge can only be solved using multiple features (for example, Chatting, Forum, Quiz, Assignment, Task, Discussion, Grouping) that exist on the e-learning platform used (Leontyeva, 2018; Newlands \& Coldwell, 2005). Selected platform by the teachers in building online learning environments that can bring up social presence and cognitive presence will determine success (Gooch \& Watts, 2015; Garrison, 2009).

This sudden learning from home demands the level of teacher readiness. In this transitional situation, almost all educational institutions, including elementary schools, try to follow ministry and government instructions to implement online learning. Teachers who have internet access tried various platforms for online learning according to their level of understanding. This learning shift also leads to some changes in teacher and student interaction behavior (van der Rhee et al. 2007; Weidlich \& Bastiaens 2019). Both try to adjust to facing technology. However, the process of adaptation and implementation of policies related to online learning has not taken into account the level of technology readiness of the teachers. By paying attention to the current online learning situation, the problem is how teachers' technological readiness in online learning is Covid-19 mitigation. With this problem, this study will measure the level of technology readiness, explore the implementation of online learning, and identify opportunities and obstacles to online learning. The results of this study will be the basis for MOEC and other education policy-makers in encouraging the improvement of the quality of education through the application of online learning. 


\section{METHODS}

\section{Settings}

This study was conducted at elementary schools in NTT, Indonesia. NTT is a province with the limitation of internet network availability. NTT consists of 22 districts. The number of elementary schools is 5329 schools spread to small islands in each district. The number of students is 815,993 students, and there are 52,957 teachers. Before the outbreak of the COVID-19, learning in the classroom dominated the activities. A week after Indonesia declared the COVID-19 emergency, the governor has issued instructions for implementing online learning. But this is not easy to implement, especially in areas where there are limited facilities. In this study, the teachers who have internet were selected as samples (111 teachers). The data were collected using an convenient sampling technique. The questionnaires were distributed via Google Form. The extremely high (all scores are 5) or extremely low (all scores are 1) data were excluded. The final respondent number is 97 (see Table 1). In this study, there were limitations associated with the level of teacher experience in implementing online learning. Generally, in NTT as a region with a low level of HDI (Human Development Index) compared to the other areas in Indonesia (Hardianto et al., 2018), there is a tendency for teachers to have never used a formal e-learning platform (such as Google Classroom, Moodle, Schoology). In exploring the actual situation, teachers tended to use social media as the primary means of interacting with students. With such a learning situation, there were limitations in interpreting e-learning or online learning that was implemented by teachers in NTT.

Table 1. Demographics Distribution of Participants

\begin{tabular}{|c|c|c|c|c|}
\hline Demographics Factors & Variable Name & Indicators & Frequency & Percent \\
\hline \multirow[t]{2}{*}{ Gender } & \multirow[t]{2}{*}{ GENDER } & Male & 41 & 42.3 \\
\hline & & Female & 56 & 57.7 \\
\hline \multirow[t]{3}{*}{ Age } & \multirow[t]{3}{*}{ AGE } & Less than 35 years & 67 & 69.1 \\
\hline & & 35 to 50 years & 29 & 29.9 \\
\hline & & More than 50 years & 1 & 1.0 \\
\hline \multirow[t]{3}{*}{ Teaching Experience } & \multirow[t]{3}{*}{ EXPERIENCE } & Less than 5 years & 44 & 45.4 \\
\hline & & 5 to 10 years & 33 & 34.0 \\
\hline & & More than 10 years & 20 & 20.6 \\
\hline \multirow[t]{6}{*}{ Grade/Level } & \multirow[t]{6}{*}{ GRADE } & 1.00 & 16 & 16.5 \\
\hline & & 2.00 & 14 & 14.4 \\
\hline & & 3.00 & 14 & 14.4 \\
\hline & & 4.00 & 27 & 27.8 \\
\hline & & 5.00 & 10 & 10.3 \\
\hline & & 6.00 & 16 & 16.5 \\
\hline \multirow[t]{2}{*}{ Hold teacher certification } & \multirow[t]{2}{*}{ CERTIFIED } & Yes & 78 & 80.4 \\
\hline & & No & 19 & 19.6 \\
\hline \multirow[t]{2}{*}{ School status } & \multirow[t]{2}{*}{ STATUS } & Private & 31 & 32.0 \\
\hline & & Public & 66 & 68.0 \\
\hline \multirow[t]{10}{*}{ School District Location } & \multirow[t]{10}{*}{ DISTRICT } & Kupang & 21 & 21.6 \\
\hline & & Alor & 10 & 10.3 \\
\hline & & Maumere & 15 & 15.5 \\
\hline & & Ende & 6 & 6.2 \\
\hline & & Manggarai Timur & 5 & 5.2 \\
\hline & & Rote Ndao & 1 & 1.0 \\
\hline & & Lembata & 14 & 14.4 \\
\hline & & Timor Tengah Utara & 4 & 4.1 \\
\hline & & Timor Tengah Selatan & 3 & 3.1 \\
\hline & & Ngada & 3 & 3.1 \\
\hline
\end{tabular}




\begin{tabular}{|l|l|l|l|l|}
\hline Demographics Factors & Variable Name & Indicators & Frequency & Percent \\
\hline \multirow{5}{*}{} & & Flores Timur & 6 & 6.2 \\
\cline { 3 - 5 } & Malaka & 2 & 2.1 \\
\cline { 3 - 5 } & Sumba Timur & 2 & 2.1 \\
\cline { 2 - 5 } & Sumba Barat & 1 & 1.0 \\
\cline { 2 - 4 } & Nagekeo & 4 & 4.1 \\
\hline
\end{tabular}

\section{Research Instrument}

The instrument used to measure Technology Readiness Index (TRI) was a questionnaire with Likert scales ranging from 1 to 5 (from Absolutely Disagree to Absolutely Agree) adopted from Parasuraman \& Colby (2001 and 2015). The questionnaire was translated from English into Indonesian. Then, it is was validated before it was used. There are 4 factors of TR: Optimism (OPT, 4 items), Innovativeness (INN, 4 items), Discomfort (DIS, 4 items), and Insecurity (INS, 4 items). Table 2 shows the matrix for each factor and item.

Table 2. Questionnaire Matrix

\begin{tabular}{|c|c|c|c|}
\hline No & Factors & $\begin{array}{l}\text { Item } \\
\text { Codes }\end{array}$ & Item Statements \\
\hline \multirow[t]{4}{*}{1} & Optimism (OPT) & OPT1 & This online learning affects me to better academic quality. \\
\hline & & OPT2 & Online learning gives me higher mobility. \\
\hline & & OPT3 & Online learning gives me greater academic control. \\
\hline & & OPT4 & Online learning makes me academically more productive. \\
\hline \multirow[t]{4}{*}{2} & $\begin{array}{l}\text { Innovativeness } \\
\text { (INN) }\end{array}$ & INN1 & $\begin{array}{l}\text { Others ask for my opinion regarding the application of } \\
\text { online learning. }\end{array}$ \\
\hline & & INN2 & $\begin{array}{l}\text { I am the first person in my work environment, trying out } \\
\text { the online learning application that was launched. }\end{array}$ \\
\hline & & INN3 & $\begin{array}{l}\text { I can immediately use online learning without others' } \\
\text { assistance. }\end{array}$ \\
\hline & & INN4 & $\begin{array}{l}\text { I always follow the development of online learning } \\
\text { applications on the things I like. }\end{array}$ \\
\hline \multirow[t]{4}{*}{3} & $\begin{array}{l}\text { Discomfort } \\
\text { (DIS) }\end{array}$ & DIS1 & $\begin{array}{l}\text { When I get technical support from online learning } \\
\text { management, I feel like I'm being used by someone who } \\
\text { knows more than myself. }\end{array}$ \\
\hline & & DIS 2 & $\begin{array}{l}\text { The technical support department is not of help because it } \\
\text { doesn't explain in a language that I can understand. }\end{array}$ \\
\hline & & DIS3 & $\begin{array}{l}\text { Sometimes I feel that online learning is not designed for a } \\
\text { layperson like me. }\end{array}$ \\
\hline & & DIS4 & $\begin{array}{l}\text { There are no guides on how to do online learning written } \\
\text { in an easily understandable language. }\end{array}$ \\
\hline \multirow[t]{4}{*}{4} & Insecurity (INS) & INS1 & $\begin{array}{l}\text { The teachers are too dependent on online learning to } \\
\text { complete their work. }\end{array}$ \\
\hline & & INS2 & $\begin{array}{l}\text { Too much online learning confuses people, even makes it } \\
\text { unfavorable. }\end{array}$ \\
\hline & & INS3 & $\begin{array}{l}\text { Online learning reduces the quality of friendships due to } \\
\text { reduced personal interaction. }\end{array}$ \\
\hline & & INS4 & I am not confident in doing online work. \\
\hline
\end{tabular}

\section{Analysis Techniques}

The main design is the ex-post facto design. There were two analytical techniques, i.e., Two-Way ANOVA, and Cluster Analysis. Two-Way ANOVA was to find out the effect of each demographic variable (See Table 1) on TR. Further, cluster analysis was applied by transforming data to Z-score, and 3 clusters were selected accordingly after iteration on cluster number. The technique applied in this analysis was the KMeans Cluster. The more in-depth analysis used field observation data. 


\section{3rd Level headings}

It gives information about the method and the process followed in the study. Cambria, 11 font, single line spacing, and first line indented $1 \mathrm{~cm}$, no space between paragraphs. It gives information about the method and the process followed in the study. Cambria, $11 \mathrm{font}$, single line spacing, and first line indented $1 \mathrm{~cm}$, no space between paragraphs. It gives information about the method and the process followed in the study. Cambria, 11 font, single line spacing, and first line indented $1 \mathrm{~cm}$, no space between paragraphs.

\section{RESULTS}

\section{Descriptive Analysis}

Table 3 shows the results of descriptive statistical analysis.

Table 3. Descriptive Statistics

\begin{tabular}{|l|l|l|l|l|l|l|l|l|}
\hline & Mean & $\begin{array}{l}\text { Std. } \\
\text { Deviation }\end{array}$ & OPT & INN & DIS & INS & TR & $\begin{array}{l}\text { Cronbach's } \\
\text { Alpha }\end{array}$ \\
\hline OPT & 13.9794 & 4.58026 & 1 & & & & & .912 \\
\hline INN & 12.9588 & 4.33474 & $.578^{* *}$ & 1 & & & & .837 \\
\hline DIS & 9.8351 & 4.59774 & -0.099 & 0.106 & 1 & & & .846 \\
\hline INS & 12.3196 & 4.38403 & -0.155 & -0.026 & $.641^{* *}$ & 1 & & .746 \\
\hline TR & 49.0928 & 11.03412 & $.539^{* *}$ & $.667^{* *}$ & $.672^{* *}$ & $.590^{* *}$ & 1 & NA \\
\hline
\end{tabular}

Table 3 shows that in all aspects of technology readiness, the teachers have high scores (see the Mean column). The standard deviation is relatively high, which means that the level of distribution is low or relatively evenly distributed to all teachers. From these results, it can be stated that in general, the teachers have the right level of technology readiness. But the analysis in detail related to the cluster and the effect of demographics is essential.

\section{Two-Way ANOVA}

This analysis was conducted to see the impact of demographic variables (see Table 1) on the level of technology readiness. This analysis was performed with the means of Total score (scale 1 to 5 ) as the dependent variable and demographic variables as the independent variable. Two aspects of this analysis are the effect of demographic variables and interactions among them. The results of the study of the impact are presented in Table 4 below. Figures 1 to Figure 4 show the interactions among the demographic variables.

Table 4. Univariate Tests

\begin{tabular}{|l|l|l|l|l|l|}
\hline Source & $\begin{array}{l}\text { Type III Sum of } \\
\text { Squares }\end{array}$ & df & Mean Square & F & Sig. \\
\hline Corrected Model & $6535.016^{\mathrm{a}}$ & 46 & 142.066 & 1.378 & .134 \\
\hline Intercept & 98404.703 & 1 & 98404.703 & 954.802 & .000 \\
\hline EXPERIENCE & 394.484 & 2 & 197.242 & 1.914 & .158 \\
\hline CERTIFIED & 55.817 & 1 & 55.817 & .542 & .465 \\
\hline STATUS & 47.208 & 1 & 47.208 & .458 & .502 \\
\hline DISTRICT & 2028.443 & 14 & 144.889 & 1.406 & .186 \\
\hline EXPERIENCE * CERTIFIED & 493.950 & 1 & 493.950 & 4.793 & .033 \\
\hline EXPERIENCE * STATUS & .000 & 0 &. &. &. \\
\hline EXPERIENCE * DISTRICT & 325.922 & 7 & 46.560 & .452 & .864 \\
\hline CERTIFIED * STATUS & .000 & 0 &. &. &. \\
\hline CERTIFIED * DISTRICT & 204.812 & 1 & 204.812 & 1.987 & .165 \\
\hline STATUS * DISTRICT & 196.101 & 4 & 49.025 & .476 & .753 \\
\hline $\begin{array}{l}\text { EXPERIENCE * CERTIFIED * * } \\
\text { STATUS }\end{array}$ & .000 & 0 &. &. &. \\
\hline
\end{tabular}




\begin{tabular}{|l|l|l|l|l|l|}
\hline Source & $\begin{array}{l}\text { Type III Sum of } \\
\text { Squares }\end{array}$ & df & Mean Square & F & Sig. \\
\hline $\begin{array}{l}\text { EXPERIENCE * CERTIFIED * } \\
\text { DISTRICT }\end{array}$ & 3.283 & 1 & 3.283 & .032 & .859 \\
\hline $\begin{array}{l}\text { EXPERIENCE * STATUS } \\
\text { DISTRICT }\end{array}$ & .000 & 0 &. &. &. \\
\hline $\begin{array}{l}\text { CERTIFIED * STATUS } \\
\text { DISTRICT }\end{array}$ & .000 & 0 &. &. &. \\
\hline $\begin{array}{l}\text { EXPERIENCE * CERTIFIED * } \\
\text { STATUS * DISTRICT }\end{array}$ & .000 & 0 &. &. &. \\
\hline Error & 5153.149 & 50 & 103.063 & & \\
\hline Total & 245468.000 & 97 & & & \\
\hline Corrected Total & 11688.165 & 96 & & & \\
\hline a. R Squared $=.559$ (Adjusted R Squared $=.153)$ & & & \\
\hline
\end{tabular}

Table 4 shows that the model is relatively good ( $\mathrm{R}$ Squared $=.559)$. No one of demographics variable affects the TR ( $\mathrm{p}$-value $=0.05)$. But together, both EXPERIENCE and CERTIFIED effects TR (Sig.= 0.033). Further analysis is to find the interaction between demographics variables. For some reason, this analysis only finds three interactions: EXPERIENCE*CERTIFIED, CERTIFIED*STATUS, and EXPERIENCE*STATUS. See Figure 1 to Figure 3 for this result.

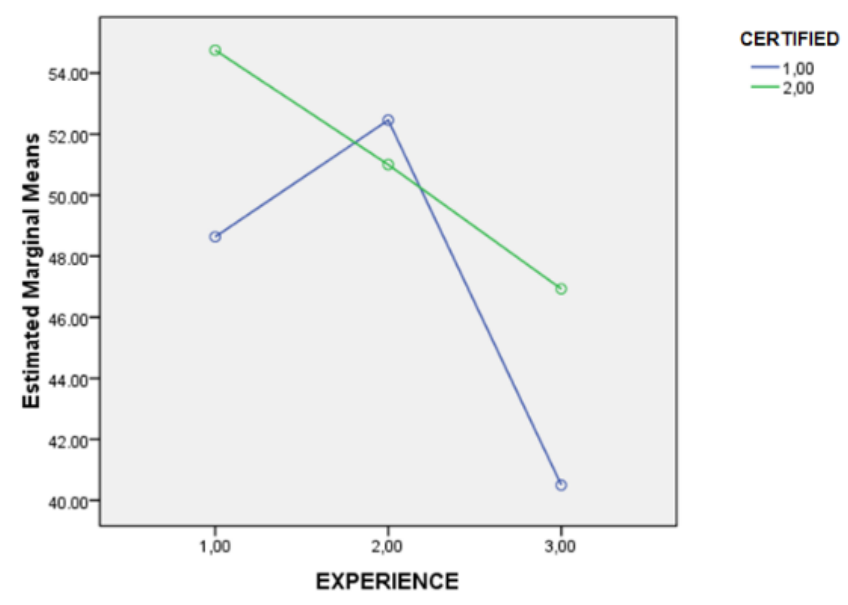

Figure 1. Interaction Experience*Certified

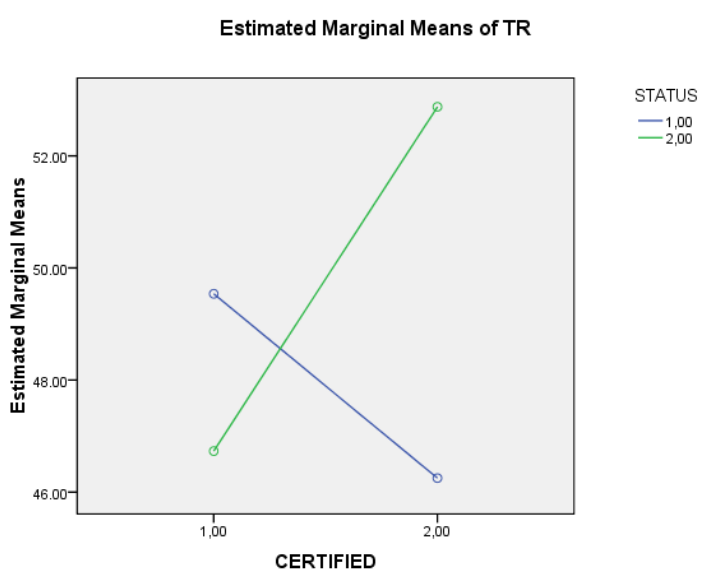

Figure 2. Interaction Certified*Status 


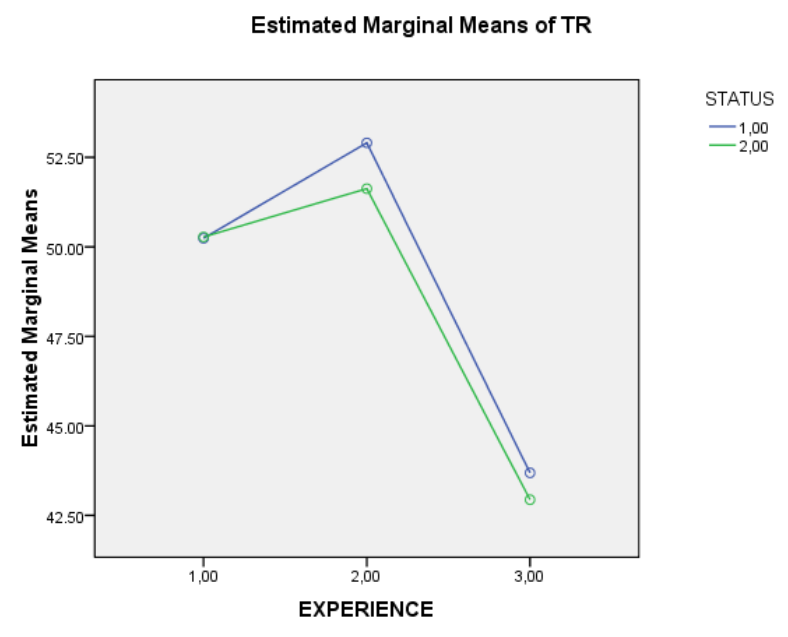

Figure 3. Interaction Experience*Status

We can find that there is the interaction between EXPERIENCE*CERTIFIED (Figure 2), and CERTIFIED*STATUS (Figure 3); but there is no interaction between EXPERIENCE*STATUS (Figure 4).

\section{Cluster Analysis}

The optimal number of clusters is selected by the Elbow method. The Elbow method uses the total of whitin sum square value as the optimal $\mathrm{k}$ determinant. The results of this method obtained with the optimal number of clusters is three. Table 5 shows the final cluster centers.

Table 5. Final Cluster Centers

\begin{tabular}{|l|l|l|l|}
\hline \multicolumn{4}{|l|}{ Cluster } \\
\hline & 1 & 2 & 3 \\
\hline Zscore(OPT1) & -.97800 & .36205 & .49110 \\
\hline Zscore(OPT2) & -.94572 & .41228 & .39129 \\
\hline Zscore(OPT3) & -.95343 & .29310 & .55926 \\
\hline Zscore(OPT4) & -1.04595 & .32655 & .60679 \\
\hline Zscore(INN1) & -.70243 & .29730 & .30261 \\
\hline Zscore(INN2) & -.75691 & .18105 & .51343 \\
\hline Zscore(INN3) & -.77554 & -.00398 & .78089 \\
\hline Zscore(INN4) & -.78678 & .13509 & .60511 \\
\hline Zscore(DIS1) & -.04114 & -.49131 & .70186 \\
\hline Zscore(DIS2) & .28642 & -.73404 & .70074 \\
\hline Zscore(DIS3) & .42022 & -.81524 & .67614 \\
\hline Zscore(DIS4) & .18374 & -.73087 & .79916 \\
\hline Zscore(INS1) & -.18709 & -.37035 & .68515 \\
\hline Zscore(INS2) & .37073 & -.70339 & .57520 \\
\hline Zscore(INS3) & .51840 & -.72076 & .45090 \\
\hline Zscore(INS4) & .68359 & -.86365 & .47787 \\
\hline
\end{tabular}

Table 5 can be converted into a bar chart to see the tendency of clusters to emerge and the clusters' characteristics. Figure 4 shows the result of Table 5 conversion. 


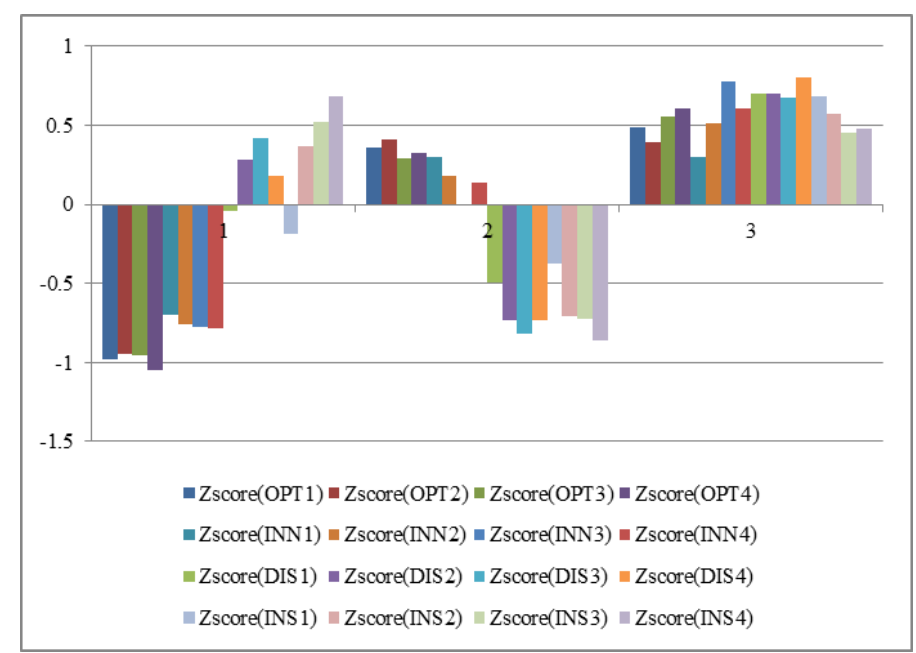

Figure 4. Cluster Diagram

\section{DISCUSSION AND CONCLUSIONS}

Many schools in Indonesia in the era of the Industrial Revolution 4.0 are trying to transform learning towards online learning (Mulyani et al. 2019; Santoso 2018). Under normal circumstances, schools have prepared various scenarios for the process of adoption and diffusion of this technology in education (Soetan \& Cokerb 2018; Faridi \& Ebad 2018). MOEC gives this obligation to schools. But due to this COVID-19 outbreak, in a sudden and fast time, all schools run online learning to survive as instructed by MOEC. Studying the characteristics of teachers in online learning readiness will be one way to achieve successful learning, including during this emergency. The management can use the results of this study used as a new basis for adoption strategies. Aspects that can be examined in this case are the issues of technology (Geng et al. 2019; Kamahina et al. 2019; Sumuer 2018). Nowadays, the internet becomes a powerful tool for learning under the right person (Wong et al. 2019). The elementary schools are the most affected by this situation, especially the schools in remote or rural areas.

The descriptive statistics show that the teachers have high scores on all aspects of technology readiness with relatively even distribution. These results indicate that teachers have the right level of technology readiness. In addition to supporting communication in the process of mutual learning between teachers, the social media channel (mainly WhatsApp) becomes an option during this COVID-19 mitigation period. In several online learning studies (both full e-learning and blended learning) in typical situations, the results show that TR influences learning achievement (Geng et al. 2019; Sunny et al. 2019). Further analysis of the level of technology acceptance will be able to help clarify the measurement results of the technology readiness level.

Based on the data analysis, it was found that there was a tendency leading to the fact that there was no effect of demographic variables on each TR indicator. It is reasonably possible that the very sudden change from face-to-face learning to fully online learning has given some results that cannot be generalized. Analysis of a case by case basis will be able to obtain a better explanation. There is much research that also examines the factors influencing TR (Tsourela \& Roumeliotis 2015; Rojas-Méndez et al. 2017). The results indicate that in typical situations, demographics are factors that need to be considered in adopting the technology. The results of this research suggest that the demographics factor has no significant effect on TR because the use of online learning is mandatory.

By using motivation theory, it can be explained that in this case, the teacher is still short in running online learning. Thus, the level of technology internalization (intrinsic motivation) reflected in TR has not been relatively influential yet. The results show that learners (in this case are teachers who use online learning) who are motivated are more likely to engage in activities that challenge, enjoy and adopt technology for their needs to show increased performance and creativity in implementing learning (Schunk et al., 2008). Thus, teachers in implementing online learning will be linked between motivation and cognitive and affective processes of individuals (thoughts, beliefs, and goals) (Brophy, 2010). When the teacher is intrinsically motivated to use online learning, he does not need external incentives that may even be counterproductive (Deci, Koestner, \& Ryan, 2001). Conversely, teachers who are extrinsically motivated to do online learning for specific reasons (Ryan \& Deci, 2000; Cook \& Artino, 2016 ), in this case, are due to the obligation of the MOEC. Thus the process of extrinsic motivation in terms of external regulation is the reason for doing online learning outside of the individual. External regulation is the type 
of extrinsic motivation most often contrasted with intrinsic motivation, where individuals are responsive to the threat of punishment or offer of reward and, as a result, tend to be obedient (Hartnett et al., 2011).

The cluster analysis results show that three clusters are the fittest. There are 3 clusters with different characteristics based on four aspects of the TR indicators. There is a model that can be used to view this clustering phenomenon. One of the models is the technology-adoption segmentation model. Technology readiness refers to the people's tendency to use new technology (in this case, it is online learning) to achieve goals in the workplace (Parasuraman \& Colby 2015). This model construct describes enabler mentality (optimism and innovativeness) and inhibitors (discomfort and insecurity) that collectively determine the tendency to use the technology (Rose \& Fogarty 2010). In this study, the actual conditions of the teachers were not revealed in detail since when they had used this online learning technology. In detail, the classification of the cluster is referred to as Parasuraman \& Colby (2015) model using data from Table 5 or Figure 5. The following Table 6 shows the summary of these clusters based on this model of technology adoption segmentation (Explorers, Pioneers, Skeptics, Paranoids, and Laggards).

Table 6. The Technology Segmentation for Each Cluster

\begin{tabular}{|l|l|l|l|l|l|}
\hline $\begin{array}{l}\text { Technology } \\
\text { Segmentation }\end{array}$ & Optimism & Innovativeness & Discomfort & Insecurity & Cluster \\
\hline Explorers & High & High & Low & Low & 2 \\
\hline Pioneers & High & High & High & High & 3 \\
\hline Skeptics & Low & Low & Low & Low & - \\
\hline Paranoids & High & Low & High & High & - \\
\hline Laggards & Low & Low & High & High & 1 \\
\hline
\end{tabular}

The technology adoption segmentation can be used to explain the formation of the cluster. This model demonstrates that in the adoption of technology, there will be five groups formed in a community associated with the level of adoption of each. By referring to the 3 clusters and also seeing the relatively high TR scores, there are only three groups that exist among the teachers, namely explorers, pioneers, and laggards.

It should be noted that the teachers apply this online learning in a very urgent, very sudden, and mandatory state (see the MOEC regulation). It must be carried out to provide learning services during the COVID-19 outbreak. As a result, there is a cluster jump. Then, the clusters of skeptics and paranoids do not appear yet. Further analysis is by taking into account the effect of subject areas on TR, using the table of cluster membership. Table 7 presents the data.

Table 7. Percentage of Subject Areas by Segment

\begin{tabular}{|l|l|l|l|l|l|l|l|l|l|l|l|}
\hline & \multicolumn{2}{|l|}{ Explorers } & \multicolumn{2}{l|}{ Pioneers } & \multicolumn{2}{l|}{ Skeptics } & \multicolumn{2}{l|}{ Paranoids } & \multicolumn{2}{l|}{ Laggards } \\
\hline EXPERIENCE & Freq & $\%$ & Freq & $\%$ & Freq & $\%$ & Freq & $\%$ & Freq & $\%$ \\
\hline $\begin{array}{l}\text { Less than 5 years } \\
(\mathrm{n}=44)\end{array}$ & 12 & 30.8 & 16 & 55.2 & - & - & - & - & 16 & 55.2 \\
\hline $\begin{array}{l}5 \text { to 10 years } \\
(\mathrm{n}=33)\end{array}$ & 20 & 51.3 & 9 & 31.0 & - & - & - & - & 4 & 13.8 \\
\hline $\begin{array}{l}\text { More than 10 years } \\
\text { (n=20) }\end{array}$ & 7 & 17.9 & 4 & 13.8 & - & - & - & - & 9 & 31.0 \\
\hline Total & 39 & 100.0 & 29 & 100.0 & - & - & - & - & 29 & 55.2 \\
\hline
\end{tabular}

Table 7 elucidates the following. For EXPERIENCE (Less than 5 years), there is a tendency for teachers to have Explorers (12), Pioneer (16), and Laggards (16) segments. All experience years can be analyzed in the same way. The result based on Table 9 shows a tendency to experience more than 10 years is dominated by Laggards ( 9 out of 20). It means that the management needs to concern the process of technology adoption, i.e., online learning, because the portion of the Laggards segment is high at every year of experience.

As discussed earlier, the COVID-19 mitigation period demands the teachers to use technology. Because it is urgent and must be immediately conducted, this tends to make segment polarization where the Sceptics and Paranoids segments do not appear. Of the existing segments, if the Laggards segment is to concern, the management should pay attention to the teacher who will be constraints of the technology adoption. The Skeptic and Paradoids segments will always question every technology adoption and supporting policies provided by the management (Lam et al. 2008; Son \& Han 2011). This result has implications on the education's policy in managing the schools and the process of technology adoption 
onwards. Education policy makers relatively need not to worry about the teacher because there are relatively many teachers in the Explorers and Pioneers segments. However, attention needs to be paid to other teachers in the Laggards segment.

These results do not yet illustrate the true situation of online learning in NTT. The number of participants who filled out questionnaires online and valid was only 97 teachers. There is an iceberg phenomenon that can be seen from the actual conditions on the ground. The statement from OEL (one of the teachers from Alor) confirmed it. The teacher stated

"Kami di daerah pedalaman yang tidak ada akses internet, sulit untuk menerapkan kebijakan (online learning) tersebut. Kami lebih pada pembelajaran dalam bentuk penugasan dengan membagi buku dan tugas ke rumah-rumah siswa."

(Translation: We are in remote areas without internet access. It is challenging to implement the (online learning) policy. We focus more on learning in the form of assignments by sharing books and tasks with students to their homes.)

Some teachers (NH from Kupang, AUR from Nagekeo) stated that although there is an internet network, not all students have mobile phones. Coping with this situation, the teacher must instead go to the students' home to deliver the assignment. This activity sometimes has to be done by using a boat to reach students who are on remote islands. In the Nagekeo area, there were complaints about the low internet access.

The policy to stop school activities is a positive step taken by the government in preventing the spread of the Covid-19 outbreak. This action is to ensure the security and safety of all school members. From the situation observation on the field, some schools in the remote area have no internet access, making it difficult to implement online learning policies. In rural areas, the principal's policy differs slightly from the government's. Teachers share learning tasks by distributing books as a reference for working on assignments (see Figure 5). Through this method, teachers ask parents to supervise learning from home.

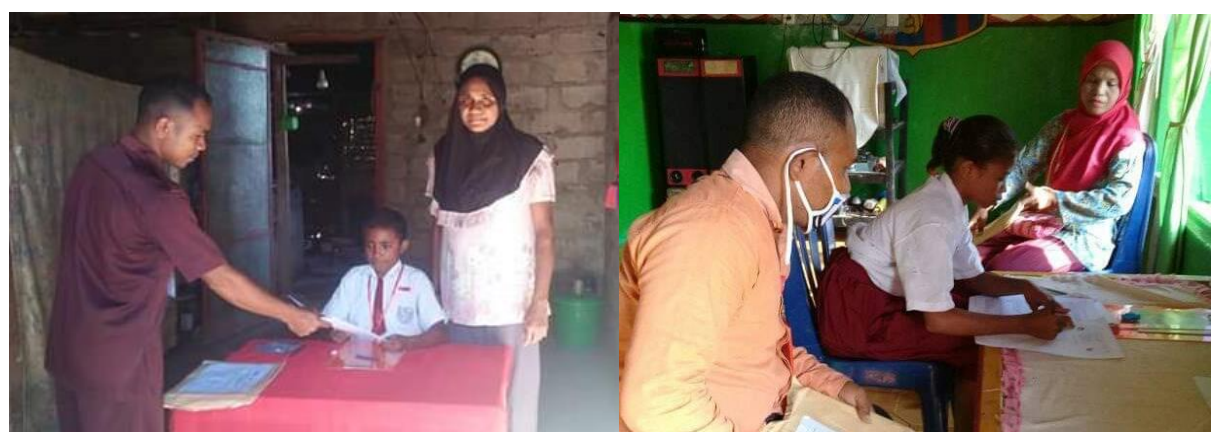

Figure 5. Teachers Visiting Students to Monitor the Learning Progress

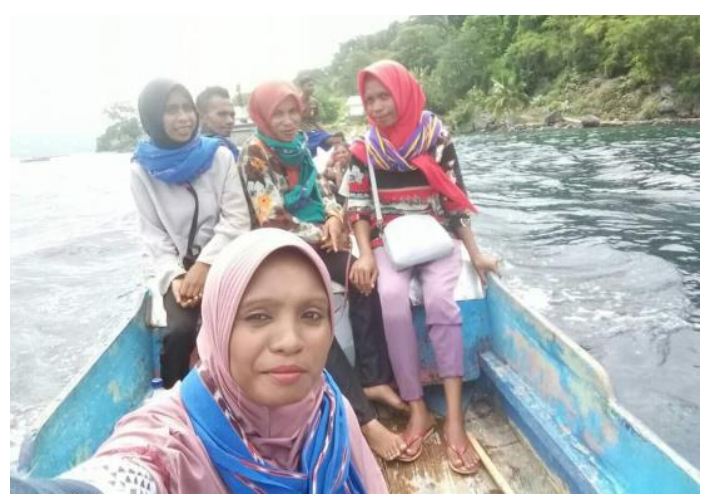

Figure 6. Teachers Were Going To Visit The Student's Home By Boat

Teachers in NTT implement various ways of learning to run. For students with internet access, the teacher applies WhatsApp-based online learning. Whereas, for students who do not have the internet access, teachers come to students to give textbook-based assignments. In certain periods, the teacher came to the students' house to monitor learning progress even though he had to use a boat to go to the remote islands (Figure 6). Of course, this is not an ideal situation in terms of MOEC policy for online learning. But this also needs to be appreciated as the creativity of the teacher to ensure that the students continue learning. 
In the group of teachers who have the desire to utilize technology in pursuance (from Explorer or Pioneer group), they face some obstacles in doing innovation. A search of this group found several innovations. Through social media networks, several questions were asked about what changes they did, why they chose those innovations, what expected impacts they hoped, and evidence of their learning innovations.

One teacher (ABR) stated that it felt more comfortable using Whatsapp for learning interactions during this mitigation period.

"Saya saat diminta untuk melakukan online learning, saya menggunakan Whatsapp. Strategi yang saya gunakan adalah mengirimkan soal-soal dan membahasnya. Pertama saya membuat grup untuk tiap kelas. Tugas yang berbeda saya berikan untuk tiap kelas. Kemuadian siswa menjawab melalui WA grup itu. Dan hasilnya dibahas bersama."

(Translation: When the regulator asked to do online learning, then I used Whatsapp. The strategy that I used is sending questions and discussing them. First, I made a group for each class. I gave different assignments for each classroom. Then students answered through the WA group. And the results were discussed together.)

The other teacher (FTR) also used the same application for ease besides having previous experience with online learning.

"Saya merasa lebih mudah memakai Whatapp untuk melakukan aktivitas pembelajaran di masa pandemik ini dibandingkan dengan aplikasi lain. Apalagi saat ini saya juga ikut kuliah yang juga dilakukan dengan cara yang sama di kampus saya."

(Translation: I find it easier to use Whatapp to do learning activities during this pandemic compared to other applications. Especially at this time, I also take an online course conducted in the same way on my campus.)

Learning innovations using Whatsapp were also carried out by other teachers, although in a relatively pure form. Activities carried out, such as proof of having done the tasks in each book in the way of self-photos, send questions in the form of photos of problems (See Figure 7).
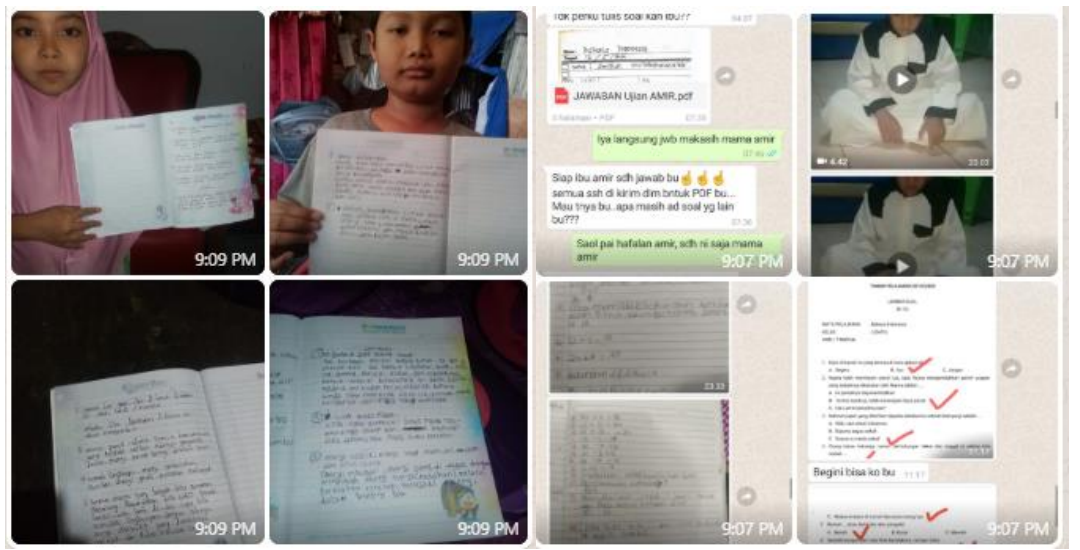

Figure 7. Students Sent Their Homework Through WhatsApp In Picture or Video

It seems that Whatsapp was still used with limited features. However, over time, the use of this technology will improve according to the level of technology acceptance by teachers and students.

The results of this study both from statistical analysis and observations in the field showsome critical findings in the implementation of online learning. Teachers, in sudden circumstances and limited facilities and experience, have tried to carry out the online learning policies. There is optimism that online learning can be a solution for learning in a new era after the pandemic is over. Even though teachers have never participated in online learning training, they try to use the most available and most commonly used applications (social media) to support learning. The teachers who change the learning was mainly from the Explorer or Pioneer group. Only from the search, the researchers did not find the teachers who have tried standard e-learning platforms (Moodle, Schoology, Google Classroom, etc.), because of the level of complexity of these applications for teachers and students who still rarely use them.

During the COVID-19 outbreak, by the regulation of MOEC, all schools completely changed the learning process from face-to-face to online learning. These changes result in sudden changes in the behavior of all teachers in the process of adopting online learning technology. This study found that demographic factors do not affect the level of teachers' technology readiness. Through more in-depth analysis, the finding confirms that the sudden change due to COVID-19 mitigation causes polarization of technological segmentation at which there are no Skeptics and Paranoids segments. Those who exist are 
only the Explorers, Pioneers, and Laggards segments appearing in three different clusters. The impact of this result is the need for special attention by education policy makers in the process of technology adoption, especially for the Laggards segment. In a normal situation, TR will affect the behavior in organizing online learning as new technology. In the field observation, because of the internet and mobilephone limitations, teachers should creatively modify the learning strategies. They must visit the student's home to ensure the learning is running well.

\section{CONFLICT OF INTEREST}

The authors declare that there is no conflict of interest in this article publication.

\section{ACKNOWLEDGEMENT}

This research was funded by Research and Community Service Institute of Ahmad Dahlan University under Collaboration Research Grant for Year 2020.

\section{REFERENCES}

Goddard, R. G., Hoy, W. K., \& Hoy, A. W. (1504). Collective efficacy: Theoretical development, empirical evidence, and future directions. Educational Researchers 33(3), 3-13.

Alshare, K. A., Freeze, R. D., Lane, P. L., \& Wen, H. J. (2011). The impacts of system and human factors on online learning systems use and learner satisfaction. Decision Sciences Journal of Innovative Education 9(3), 437-461.

Brophy, J. (2010). Motivating students to learn (3rd ed.). New York, NY: Routledge.

Cole, M. T., Shelley, D. J., \& Swartz, L. B. (2014). Online instruction, e-learning, and student satisfaction: A three year study. The International Review of Research in Open and Distributed Learning 15(6), 111131.

Cook, D. A., \& Artino Jr, A. R. (2016). Motivation to learn: an overview of contemporary theories." Medical education 50(10), 997-1014.

Deci, E. L., Koestner, R., \& Ryan, R. M. (2001). Extrinsic rewards and intrinsic motivation in education: Reconsidered once again. Review of Educational Research 71(1), 1-27.

Faridi, M. R., \& Ebad, R. (2018). Transformation of higher education sector through massive open online courses in Saudi Arabia. Problems and Perspectives in Management 16(2), 220-231.

Garrison, D. R. (2009). Communities of inquiry in online learning: Social, teaching and cognitive presence." In C. Howard et al. (Eds.), Encyclopedia of distance and online learning (2nd ed., pp. 352355). Hershey, PA: IGI Global.

Geng, S., Law, K. M., \& Niu, B. (2019). Investigating self-directed learning and technology readiness in blending learning environment. International Journal of Educational Technology in Higher Education 16(1), 17.

Gooch, D., \& Watts, L. (2015). The Impact of Social Presence on Feelings of Closeness in Personal Relationships. Interacting with Computers 27(6), 661-674.

Gray, J. A., \& DiLoreto, M. (2016). The effects of student engagement, student satisfaction, and perceived learning in online learning environments. International Journal of Educational Leadership Preparation 11(1), 1-20.

Hardianto, A.M., Tjahjadi, B., \& Narsa, I. M. (2018). Human Development Index (HDI) as a planning plan for dealing globalization of ASEAN Economic Society (MEA) in Indonesia. Proceedings of the ICECRS $1(2)$.

Hartnett M, St George A, \& Dron J. (2011). Examining motivation in online distance learning environments: Complex, multifaceted, and situation-dependent. International Review of Research in Open and Distributed Learning 12(6), 20-38.

Kamahina, R. S., Yakovenko, T. V., \& Daibova, E. V. (2019). Teacher's Readiness to Work under the Conditions of Educational Space Digitalization. International Journal of Higher Education, 8(7), 1-22.

Lam, S. Y., Chiang, J., \& Parasuraman, A. (2008). The effects of the dimensions of technology readiness on technology acceptance: An empirical analysis. Journal of Interactive Marketing 22(4), 19-39.

Leontyeva, I. A. (2018). Modern distance learning technologies in higher education: Introduction problems. Eurasia Journal of Mathematics, Science and Technology Education 14(10): em1578.

Mulyani, S. R., Ramadhanu, A., Sari, D. P., Arsyah, R. H., \& Nengsih, N. S. W. (2019). Convergence Analysis of Acceleration and Generalization of E-Learning in the Manifestation of Globalization Education Readiness 4.0. Journal of Physics: Conference Series 1339(1), 012078). 
Newlands, D. A., \& Coldwell, J. M. (2005). Managing student expectations online.” In International Conference on Web-Based Learning (pp. 355-363). Springer, Berlin, Heidelberg..

Parasuraman, A., \& Colby, C. L. (2001). Techno-ready marketing: how and why your customers adopt technology. New York: The Free Press.

Parasuraman, A., \& Colby, C. L. (2015). An updated and streamlined technology readiness index: TRI 2.0. Journal of Service Research 18(1): 59-74.

Rojas-Méndez, J. I., Parasuraman, A., \& Papadopoulos, N. (2017). Demographics, attitudes, and technology readiness: A crosscultural analysis and model validation. Marketing Intelligence and Planning 35(1), 18-39.

Rose, J., \& Fogarty, G. J. (2010). Technology readiness and segmentation profile of mature consumers. Proceedings of the 4th Biennial Conference of the Academy of World Business, Marketing and Management Development (Vol. 4, No. 1, pp. 57-65). Academy of World Business, Marketing and Management Development.

Ryan, R. M., \& Deci, E. L. (2000). Intrinsic and extrinsic motivations: Classic definitions and new directions. Contemporary Educational Psychology 25(1): 54-67.

Santoso, H. B. (2018). Indonesian Perspective on Massive Open Online Courses: Opportunities and Challenges. Journal of Educators Online 15(1).

Schunk, D. H., Pintrich, P. R., \& Meece, J. L. (2008). Motivation in education (3rd ed.). Upper Saddle River, NJ: Pearson Merrill Prentice Hall.

Soetan, A. K., \& Cokerb, A. D. (2018). University teachers' readiness and motivation in utilizing online technologies for instructional delivery in Kwara state, Nigeria. World Journal on Educational Technology 10(4), 165-181.

Son, M., \& Han, K. (2011). Beyond the technology adoption: Technology readiness effects on postadoption behavior. Journal of Business Research 64(11), 1178-1182.

Sulisworo, D., Kusumaningtyas, D. A., Bergita, A. A., Wahyuningsih, W., \& Widya, R. (2020). Perceptions of Online Learning Experiences between Students in Urban and Remote Areas: Case Study in Indonesia. International Journal of Scientific \& Technology Research 9(2): 4850-4854.

Sumuer, E. (2018). Factors related to college students' self-directed learning with technology. Australasian Journal of Educational Technology 34(4), 29-43.

Sunny, S., Patrick, L., \& Rob, L. (2019). Impact of cultural values on technology acceptance and technology readiness. International Journal of Hospitality Management 77, 89-96.

Tsourela, M., \& Roumeliotis, M. (2015). The moderating role of technology readiness, gender, and sex in consumer acceptance and actual use of Technology-based services. The Journal of High Technology Management Research 26(2), 124-136.

van der Rhee, B., Verma, R., Plaschka, G., \& Kickul, J. (2007). Technology readiness, learning goals, and elearning: searching for synergy. Decision Sciences Journal of Innovative Education 5(1), 127-149.

Weidlich, J., \& Bastiaens, T. J. (2019). Designing sociable online learning environments and enhancing social presence: An affordance enrichment approach. Computers \& Education 142, 103622.

Wong, J., Baars, M., Davis, D., Van Der Zee, T., Houben, G. J., \& Paas, F. (2019). Supporting self-regulated learning in online learning environments and MOOCs: A systematic review. International Journal of Human-Computer Interaction 35(4-5), 356-373. 